
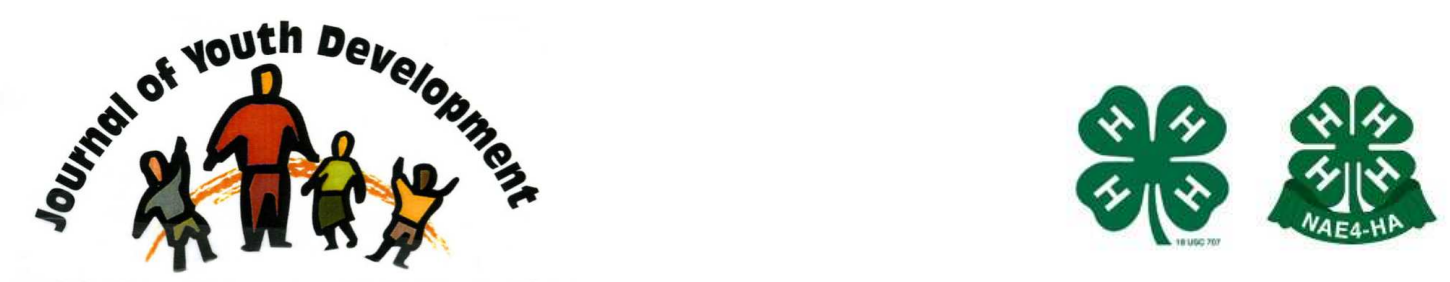

Bridging Research \& Practice

\title{
New Designs for Participatory Research: Modified Photoethnography and the Personal Resource Systems Management (PRSM) Model
}

\author{
Cindy Beacham \\ West Virginia University \\ Morgantown, WV \\ cindy.beacham@mail.wvu.edu \\ Barbara McFall \\ West Virginia University \\ Morgantown, WV \\ barbara.mcfall@mail.wvu.edu
}




\title{
JOURNAL OF YOUTH DEVELOPMENT \\ bridging research and practice

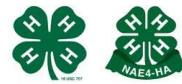

Volume 4, Number 2, Summer 2009

Article 090402RS002

\section{New Designs for Participatory Research: Modified Photoethnography and the Personal Resource Systems Management (PRSM) Model}

\author{
Cindy Beacham and Barbara McFall \\ West Virginia University
}

\begin{abstract}
Learning environments significantly influence student behaviors, academic success, school attendance and participation, all of which are problematic today. Less than half of high school students surveyed in 2005 would select the same high school again if given the opportunity, and only $38 \%$ agreed that the support they get at school encourages them to learn more. Pursuing increased educational effectiveness, this paper discusses a study that gathered and evaluated middle and high school students' concepts of ideal student-centered learning environments in selected classrooms. This multi-method, participatory approach put cameras in student hands and ask them to photograph elements desired in their ideal classroom, "things that help you learn." Interviews were conducted to explore the meaning behind each photo. Analysis was performed using the Personal Resource Systems Model (PRSM). Findings clearly indicate existing physical and emotional needs, left un-addressed by No Child Left Behind, that might be met by improving the material and social classroom environment.
\end{abstract}

\section{Introduction}

Americans feel that one of the main purposes of education is to prepare students to become responsible citizens (Rose \& Gallup, 2000) - the type of adults that help make the world a better place. The public also believes strongly (88\%) that the achievement gaps associated with ethnicity and socio-economic status must be closed. Of those responding to the 2005 Phi Delta Kappa/Gallup Poll, 74\% attribute the gap to factors other than schooling, but $56 \%$ say it is the responsibility of the schools to close it (Rose \& Gallup, 2005). Successful living in the 21st century will require both, self-management and lifelong learning, according to prominent business leaders (Drucker, 1999; Peters, 1994). Psychologists and educators contend that 
development of these personal capabilities is dependent upon adequate nurture (Brazelton \& Greenspan, 2000; Garbarino, 1999; Search Institute, 1997a \& b; Sergiovanni, 1992).

The mandate goes well beyond mastering data and information (standards). The mandate speaks to the knowledge required for daily application and the wisdom of choice and is the vital issue of our time. Secondary and traditional undergraduate students (15-24 year olds) represent a significant portion of our population and the immediate future of our society. The 2000 Census reported over 39 million Americans (13.9\% of the total population) transitioning from childhood to adulthood, most of whom attend school. Yet the coming-of-age remains rocky. Violence and suicide are the number 2 and 3 causes of death for this segment of the population (U. S. Department of Health and Human Services, July 24, 2000). Motor vehicle accidents often linked with drinking and drugs, were number one.

During the 1996-1997 school year, the Search Institute (1997 a \& b) studied nearly 100,000 youth in 312 towns to find specific contributors to the emergence of unacceptable behaviors. They found a complex but significant relationship between factors they termed "developmental assets" (i.e. support, empowerment, clear boundaries and expectations, constructive use of time, commitment to learning, positive values, social competencies and positive identity) and illicit drug use, violence, health, and success in school. The study indicated that the average American 6th-12th grader experienced only 18 of 40 assets traditionally flowing from home, family, and friends.

Yet these assets are vital. Only $1 \%$ of youth reporting $31-40$ assets used drugs as opposed to $42 \%$ of those limited to $0-10$ assets. The rate of violence was $6 \%$ among the highest asset group and $61 \%$ among the lowest. Good health was reported by $88 \%$ of high asset responders but by only $25 \%$ of low asset participants. Success in school also reflected these trends, with $53 \%$ of high asset students reporting success in school as opposed to $7 \%$ of low asset students. Subsequent studies yielded remarkably similar results.

Low asset rates and poor test scores are also correlated with childhood poverty. The Trends in International Mathematics and Science Study (Gonzales, et al., 2008) showed that wealthy schools (less than $10 \%$ poverty) posted fourth grade and eight grade science and math scores well above the US and International averages. Schools with poor students (75\% poverty) posted scores approximately 100 points or $20 \%$ lower. Poverty short-changes children across a wide range of family and community assets leaving them simply not ready to learn.

Given the impact of all non-academic factors on school success, public education might have stepped in to fill the gap. In The schoolhome: Rethinking schools for changing families, Jane Roland Martin (1992) suggests that 3 C's (care, concern, and connectedness) should share equal billing with the 3 R's (reading, 'riting, and 'rithmetic) in education. Lynn Jenks (2001, p. 17) asserts: "the ideas, ideals, and the procedures of creating designs for living and handling age appropriate problems should be an essential part of the curriculum from elementary school through secondary school." Closer mentoring generally results in more engaged students and research indicates that engaged students get more from school on all levels than their disengaged peers (Fredericks, Blumenfeld \& Paris, 2004; National Research Council, 2004; Norris, Pignal, \& Lipps, 2003). Sadly, the High School Survey of Student Engagement 2005 $(80,094$ students in 2005 and a total of 180,000 since 2004$)$ found that more than $52 \%$ of students had not discussed ideas from their readings with a teacher outside class during the school year. Sixty percent had not communicated with a teacher by e-mail and less than half $(48 \%)$ said that they had frequently discussed grades or assignments with a teacher. Not 
surprisingly, only $53 \%$ of all respondents agreed that they cared about their current school, and $47 \%$ were disinclined to select the same high school again if given the opportunity. Slightly more than half $(55 \%)$ felt safe at school.

Some analysts have suggested that the secondary curriculum in Family and Consumer Sciences (F \& CS) be repositioned to supplement engagement and developmental assets within the standard school day (McFall \& Mitstifer, 2005). For more than a century, F \& CS practice has espoused a mission that included in some fashion - nurturing the individual and improving quality of life [building assets] through improving the relationship between people and their environment [enhancing engagement] (AHEA, 1993). The F \& CS core is unique in academic circles; its approach to education is subjective, multidisciplinary, holistic/systemic, and applied. Linked to the community through cooperative extension, F \& CS is poised to provide balance to, and more importantly a foundation for, the content standards established by No Child Left Behind.

\section{The Research Question}

As Interior Design Educators at a Land Grant University, we decided to explore our small corner of the larger problem. Research shows that environment strongly impacts IQ (Berliner, 2005, p. 23; Turkheimer, et al., 2003) and that classroom design has a significant effect on behavior and learning (e.g. Dodd, 1997; Colbert, 1997). Furthermore, greater changes are expected to occur for the poor than the non-poor as positive changes in their environments occur (Berliner, 2005, p. 36). Anne Taylor, Director of the Institute for Environmental Education, observes:

This is an intensely active time in school construction, and yet schools are built or renovated every day without input from students. Architects design monuments to themselves instead of places to support learning and curriculum. Educators occupy environments and use equipment they don't fully understand and can't exploit to the fullest. Children learn to tune out the environment rather than to develop awareness and a sense of belonging. Now is the time for foresight, inclusion, and planning, not ten years from now (2001).

That said, it might be noted that many if not most classrooms, including Family and Consumers Sciences classrooms, seem to have evolved with limited understanding of the effect of rich and complex environments on student attitudes and behaviors. How, we wondered, might F \& CS classrooms be redesigned to help build learner assets and enhance student engagement?

Taylor insists that "all stakeholders, from students to community, must be involved in the programming and design of learning environments." She advocates a model for participatory planning, which "establishes a system for learning across student developmental needs of the body, mind, and spirits; integrated subject matter disciplines; and learning processes." The envisioned educational system informs the design of the built, natural, and cultural environment so that the resultant environment serves as a three-dimensional textbook (2001).

This line of reasoning led us to question what contextual supports students might perceive as beneficial to their learning. We decided to let the students tell us directly. The stated academic purpose of this pilot study was to "determine student perceptions of an ideal 'student-centered' classroom through photographic representations." The findings, if useful, might find further application as preliminary programming for the design of a pilot classroom for Family and Consumer Sciences (FCS) and perhaps eventual adoption of that design by public secondary schools nationwide. 


\section{Methodology}

Designers are visual people so we took a multi-method visual approach that allowed researchers to collect visual images from the students and clearly understand their intent behind the images.

Theory. First, we introduced a graphic model of learner in context. The PRSM model views the learner as being at the center of a multiple contextual interactions. In this convention, elements to be experienced are referenced around 6 named environmental dimensions (intellectual, organizational, social, material, natural, financial). (see Figure 1).

Figure 1

The PRSM Model of Personal Resource Systems Management.

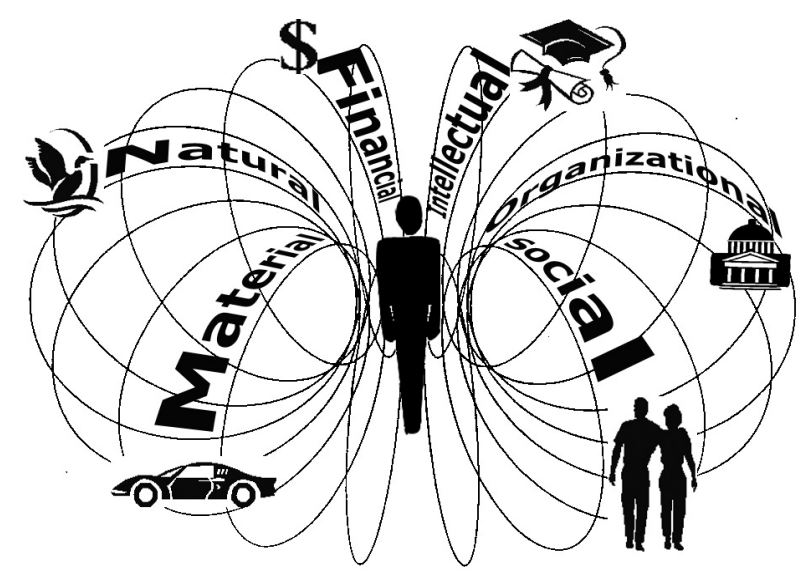

Adapted from "Personal Resource Systems Management: A Proposal for Interactive Practice" by B. McFall, 1998, p. 125. Unpublished master's thesis. Copyright 1998, (B. McFall, 1998)

The human agent at the center of this system engages his/her environment through 3 aspects (mental, emotional, physical). The beauty of this systems' view is that participants are forced to consider social issues as well as intellectual ones; financial influences as well as organizational plans, etc. They are also required to consider the emotional side of daily experience as well as mental and physical.

The three personal aspects (physical, emotional, mental) and six environmental dimensions (intellectual, organizational, social, material, natural, financial) delineate 18 distinct interactions ( 3 aspects $x 6$ dimensions) for further study. Each interaction group is stylistically unique and requires consideration on its own terms (see Figure 2 ). 
Figure 2

Named quality-of-living interactions in the PRSM paradigm.

From Future promise: Designing Personal Resource Systems Management as a platform for living and learning by B. McFall, (2002).

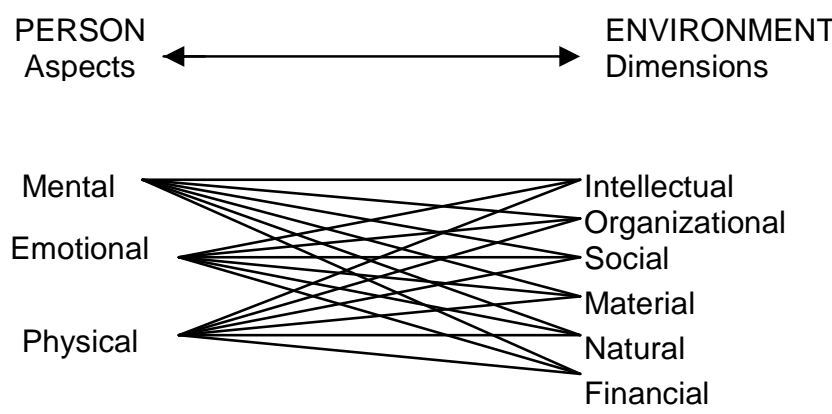

These interactions can also be represented in matrix format. Within the matrix format, the eighteen qualities of living sum by row to environmental satisfactions (i.e. social satisfaction, financial satisfactions), by column to personal well-beings (i.e. mental well-being, emotional well-being, physical well-being), and overall/over time to Quality of Life (see Figure 3).

Figure 3

Matrix format for PRSM data.

From Future promise: Designing Personal Resource Systems Management as a platform for living and learning by B. McFall (2002).

\begin{tabular}{|l|l|l|l|l|}
\hline \multicolumn{1}{|c|}{ MENTAL EMOTIONAL PHYSICAL SATISFACTION } \\
\hline INTELLECTUAL & & & & \\
\hline ORGANIZATIONAL & & & & \\
\hline SOCIAL & & & & \\
\hline MATERIAL & & $\begin{array}{l}\text { Quality of } \\
\text { living }\end{array}$ & & \\
\hline NATURAL & & & & \\
\hline FINANCIAL & & & & \\
\hline WELL-BEING & & & & $\begin{array}{l}\text { QUALITY } \\
\text { of LIFE }\end{array}$ \\
\hline
\end{tabular}

Data Collection. At the time that data was collected in 2003, the PRSM model had been piloted as a course module in the participating Erie classrooms for five years. The students were well oriented to that way of systems thinking. Most of them had completed personal PRSM portfolios describing their life in context. In this pilot study, photoethnography was used as a primary 
methodology to allow students the freedom to visually represent their ideas for classroom characteristics without being "led" by researcher-identified concepts. Also called photo-elicited interviews or visual ethnography, photoethnography is growing in popularity among visually oriented research fields (Clark-Ibanez, 2004). Photoethnography allows the participants to express their inner thoughts through visual means (photos), and provides an opportunity through an associated interview to express the meaning behind each photo. The photoethnography was supported by individual interviews with each photographer to clarify their representations. The photoethnographic methodology not only encouraged the sharing of their ideas, but also provided an enjoyable activity to provide fun while they were "working".

To establish a benchmark, we began with a population representative of the "standard" view of public education - the type of school that politicians envision when policies are handed down. These visions include schools that are newer, clean, middle-class, and generally high performing. The participating schools were chosen from several within the Pennsylvania school district currently implementing the PRSM approach in their Family and Consumer Sciences classrooms. By including students familiar with systems thinking, representations were more thoughtful and relevant for the specific learner-centered classroom that was the focus of the study.

The researchers wanted to incorporate perceptions from both high school and middle school students to provide a range of developmental interpretations, and to explore possible differences identified between the two age groups. The district F \& CS coordinator provided suggestions for one high school and two middle schools that would be appropriate for use in our study. The students in each F \& CS classroom were representative of the diversity of the school district, the students had been involved in the PRSM program for over one year, and the teachers were willing to have their classes participate in the study. One high school F \& CS class $(n=22)$ and two middle school classes $(n=33)$ were ultimately involved in the pilot study. Teacher commitment was an important component since several activities over the course of the project were conducted during the F \& CS class time.

Participating F \& CS teachers typically taught 4-5 different groups of students during the course of one day. We asked the teachers to choose one class group that represented their general student body and that they felt would be willing to be involved in the project. Each of the three teachers, in consultation with their district coordinator, chose the most appropriate group of students for the study, and provided the researchers with the names of the students and the class time they would be available. Students were informed of the study and asked if they would like to participate. While students were given the opportunity to decline, the overwhelming majority of students in each class chose to participate and indicated an excitement at being chosen to contribute their efforts to the study.

All appropriate IRB permissions were obtained. Prior to the project start, an introductory packet for each student was sent to the teachers in all 3 schools for distribution. The packet included a full description of the project, an explanation of activities within which the students would be involved, an assurance that the activities would not cost the student any money, and permission slips for both parents and students to sign. Descriptions covered both the photographic activity and the interview to be conducted at the completion of the photo portion. Each student was provided an opportunity to decline to participate without penalty, and no students were included without parental and personal permission slips on file. Permission packets were distributed to approximately 60 students; 55 returned the signed forms and participated in the activities. 
The teachers were asked to be the researchers' liaisons only to the extent of distributing and collecting packets. Classroom responsibilities for teachers are enough, and we did not want to burden them with additional tasks. Some teachers did choose to become more involved by way of monitoring student participation and including the activity in their classroom units. Other teachers willingly distributed and collected the packets without additional contribution. Teachers were asked not to include student participation or products in the grading structure for the grading period, and it was understood that the student work for this project was considered confidential unless the student chose to share their work with others. Since the researchers made it clear to the students that their participation was voluntary, we had assumed that the teachers would not be critical of students who chose not to participate. This was generally the case, but we believe that specific instructions to teachers indicating our commitment to student's right to choose without consequences or disapproval must be provided in writing at the beginning of future data-collection periods.

Upon collection of the signed permission packets provided by the students wishing to contribute, the researchers scheduled trips to each of the participating schools. Personal visits were made by the two researchers and the assistant to each classroom to explain the study, respond to questions, and distribute data collection packets. The personal explanation of the study and providing a "face" to go with the work encouraged students and they greeted us with an unexpected level of excitement about the project.

During the visits students were provided with pre-made packets constructed by the researchers. The packets contained a clear instruction sheet with start and finish dates, an "idea-generating" sheet with possible questions to consider to jump-start their thinking about the classroom, a set of notation sheets to record their reasons for taking each picture, and a disposable camera. Each packet was numbered, and the camera within the packet was marked with the same number. To alleviate any possible confusion during the developing of the pictures, we also took a picture with the camera of a card with the camera number on it as the first picture of each roll. As each packet was distributed, the student name(s) and associated packet numbers were recorded. The researchers' initial intention was to provide each student with an individual packet so they could develop their visual representations on their own. As the distribution began, students requested to work with a partner, so we allowed students to choose to work alone or with a friend to denote their personal images for a new classroom. We answered additional questions after the students had an opportunity to review the contents of the packet, then we left the classrooms. Each class was given two weeks to take their photographs and return their completed packets to their teacher. Students only needed to return the camera, but many included their note sheets also.

Teachers were provided with pre-addressed, pre-paid overnight mailing boxes and asked to place all of the returned materials in the box and send it to us as soon as possible after the student deadline. All boxes were returned, and the photos were developed and organized as they were received. Each photograph was assigned a number that included the camera number and the picture number. Photos were labeled on the backs, a small label with the number was also placed on the front of the picture, and the picture was inserted into a plastic photo page. A folder was created for each roll of film and all picture pages as well as note pages (also numbered) were inserted into the folder. Each folder was labeled with the student/camera number on the front for ease of retrieval. The level of redundancy in labeling was determined necessary to assure that pictures could be returned to their proper folder if they became separated and mixed with photos from other students. 
After the pictures were developed and organized within their respective folders, the researchers contacted the teachers to schedule time to conduct face-to-face interviews with each of the participating students. Individual interviews were conducted with each student or pair of students, and participants were asked to explain their reasons for taking each picture and how it related to the redesign of the $\mathrm{F} \& \mathrm{CS}$ classroom. To minimize the amount of time disruption to any particular classroom, interviews were conducted by the two primary researchers and the research assistant. Interviews were scheduled outside the classroom, and approximately 10 minutes were allotted for each interview. Formatted note-taking pages were provided to each of the researchers conducting the interviews, and all interviews were audio recorded and transcribed for further clarification of data. Students were asked to bring their note pages to refer to during the interview if they had not submitted them with the camera packet. We provided students with their hand-written notes for the interview if they included them in the camera packet.

The interviews consisted mainly of the students describing their reasons for taking each picture and how that representation showed a specific element, item, or idea that should be incorporated into the new, student-centered F \& CS classroom. At the completion of the discussion about the pictures, students were asked three additional questions. First they were asked if there was anything else they would like to share or any additional pictures they would like to have included and why. Second, they were asked how they felt about being asked to participate in the project. Finally, they were asked if there was anything they could suggest to improve the activity or the project.

Analysis. All interviews were transcribed and data was organized based on the PRSM framework. The 55 participants provided over 350 pictures to be sorted, coded, and discussed. Each participant who worked on the photographic portion of the project also participated in the individual interviews, so all sets of photographs had accompanying explanations. The recordings taken during the interviews were all transcribed by the research assistant, and the transcripts were evaluated for content, clarity, and types of responses. With the exception of the final three questions described above, qualities of living were identified from student responses by recurring key terms that were assigned to appropriate cells within the PRSM matrix. Numbers of respondents using that term or an equivalent were noted.

\section{Findings}

Overwhelming consistency was found in the ideas expressed by the students. Forty individual characteristics were identified as important to the students and included elements such as environments that allowed for comfort and relaxation; more interest in the classroom by using color, details, and art; variety and flexibility in lighting; more supportive furniture; and more access to resources such as reference books, computers, and magazines.

When analyzed through the PRSM model, three major areas of concern emerged. First, students felt a need to have the material dimension modified to provide more emotional support in the classroom. This was represented by items such as more detailing within the space, lamps, candles, window treatments, and art/posters. 
The second area of emphasis identified was the need to modify the material dimension to provide more physical support in the classroom. Pictures of soft seating, comfortable study furniture, additional storage, and temperature controls signify a need to change the balance between the material and physical areas.

Finally, photographs illustrated a need to manipulate the social dimension to improve students' emotional states. These photographs included animals, friends in classes, and elements that provided a "homey feel" within the space.

Students were also asked their feelings about being asked to participate in the project during the individual interviews. The responses were overwhelmingly positive, and most students felt excited and honored that someone wanted to hear what they had to say about their own classroom spaces!

The PRSM matrix is the tool used for organizing and analyzing the data gathered from the photos and interviews with students (see Figure 4). Each cell in the matrix describes a personenvironment interaction in terms of one personal aspect (mental, emotional, physical) and one environmental dimension (intellectual, organizational, social, material, natural, financial). For instance, the cell highlighted in green is concerned with a physical experience of a social environment (i.e. lack of breakout spaces). 
Figure 4

Student data from interviews organized with PRSM matrix. $(\mathrm{N}=55)$

\begin{tabular}{|c|c|c|c|c|c|c|c|}
\hline & Mental & & Emotional & & Physical & & $\begin{array}{c}\text { Total } \\
\text { Environ. } \\
\text { Satisfaction }\end{array}$ \\
\hline \multirow[t]{2}{*}{ Intellectual } & $\begin{array}{l}\text { Interesting } \\
\text { things to do in } \\
\text { spare time } \\
\text { More visually } \\
\text { interesting }\end{array}$ & $\begin{array}{l}24 \\
06\end{array}$ & $\begin{array}{l}\text { Display of personal } \\
\text { items }\end{array}$ & 11 & & & \\
\hline & & 30 & & 11 & & & 41 \\
\hline \multirow[t]{2}{*}{ Organizational } & & & & & Comfort for teachers & 03 & \\
\hline & & & & & & 03 & 03 \\
\hline \multirow[t]{2}{*}{ Social } & & & $\begin{array}{c}\text { Real Animals } \\
\text { Friends in Class } \\
\text { Animal } \\
\text { representations } \\
\text { Improved bathroom } \\
\text { access* } \\
\text { Cell phones } \\
\text { Homey feel } \\
\end{array}$ & $\begin{array}{l}28 \\
28 \\
10 \\
07 \\
05 \\
05 \\
\end{array}$ & $\begin{array}{l}\text { Small breakout rooms } \\
\text { (proximity) }\end{array}$ & 07 & \\
\hline & & & & 83 & & 07 & 90 \\
\hline \multirow[t]{2}{*}{ Material } & $\begin{array}{l}\text { Computer } \\
\text { access } \\
\text { Book access }\end{array}$ & $\begin{array}{l}15 \\
02\end{array}$ & $\begin{array}{c}\text { Color on Walls } \\
\text { Stereo/Music } \\
\text { Art/posters } \\
\text { Lamps } \\
\text { Candles/scents } \\
\text { Window treatments } \\
\text { Fireplace } \\
\text { Better ceiling } \\
\text { treatments }\end{array}$ & $\begin{array}{l}24 \\
24 \\
23 \\
18 \\
11 \\
07 \\
06 \\
01\end{array}$ & $\begin{array}{c}\text { Sofas/soft seating } \\
\text { VCR/TV/DVD } \\
\text { (available/placement) } \\
\text { Pillows } \\
\text { Comfortable study } \\
\text { furniture } \\
\text { Temp. control } \\
\text { Place for personal } \\
\text { items } \\
\text { Storage } \\
\text { Better light } \\
\text { Place for naps } \\
\text { Trash can placement } \\
\text { More space } \\
\end{array}$ & $\begin{array}{l}37 \\
20 \\
\\
11 \\
11 \\
\\
09 \\
\\
08 \\
07 \\
03 \\
02 \\
02 \\
01 \\
\end{array}$ & \\
\hline & & 17 & & 114 & & $\begin{array}{c}11 \\
1\end{array}$ & 225 \\
\hline \multirow[t]{2}{*}{ Natural } & & & $\begin{array}{c}\text { Plants/Nature } \\
\text { Access to outdoors }\end{array}$ & $\begin{array}{l}15 \\
05\end{array}$ & $\begin{array}{c}\text { Food/drinks } \\
\text { Water in class } \\
\text { Fire extinguishers }\end{array}$ & $\begin{array}{l}25 \\
07 \\
01\end{array}$ & \\
\hline & & & & 20 & & 33 & 53 \\
\hline \multicolumn{8}{|l|}{ Financial } \\
\hline $\begin{array}{l}\text { Total PERSONAL } \\
\text { WELL-BEING }\end{array}$ & & 47 & & 228 & & $\begin{array}{c}15 \\
4\end{array}$ & \\
\hline
\end{tabular}

During the transcription of the student interviews, key terms were identified and included in the PRSM matrix above. Each time a student referenced a key term or term similar, their response was entered into the matrix. For example, students identified their desire to have or interact with "real animals" 28 times within the interviews. Based on the conversations and the context within which they discussed the "real animals", the researchers identified this need as part of 
the social dimension/emotional environment satisfaction on the PRSM matrix. Other elements that represented the social/emotional satisfaction included friends in class, animal representations, improved bathroom access, cell phones, and a homey feel. These topics were referenced a total of 83 times within the interviews conducted. Responses are tallied in rows to determine environmental satisfaction, and in columns to determine personal well being.

\section{Discussion: Further Research}

Other Stakeholders. Additional data (mandates and constraints) are needed from parents, teachers, administrators, staff and other stakeholders before a final recommendation can be made for the re-design of $\mathrm{F} \& \mathrm{CS}$ classroom. That data is currently being collected and analyzed.

Design Proposals. Viable designs based on the student input as well as input from other stakeholders are necessary to move the information collected from this project into reality. Third and fourth year interior design students will create designs in a charrette format to provide initial visual responses to the data for review. The charrette is a frequently used method in design fields to produce several designs based on given parameters within a short amount of time. Participants will work in teams, and the guidelines for the project will be provided to each team at the same time. Teams will be given a restricted timeframe, and will be required to produce a viable solution to the design problem at the conclusion of the given time. Solutions are to be presented to an audience of reviewers, and designs are evaluated on the basis of the appropriateness of their end result. For the purposes of this project, each design would be presented to the students, teachers, administrators, parents, and other stakeholders, and critiques of each solution would be solicited. With all of the feedback in place, a final design based on a compilation of all input will be created.

Critical Evaluation. Ethnographies involve the study of a) an intact cultural group b) in a natural setting c) during a prolonged period of time d) by collecting, primarily observational data (Creswell, 1994; Wallen \& Fraenkel, 1991). Critical ethnographies are a subset of that process in which the researcher "chooses between conceptual alternatives and value-laden judgments to challenge research, policy, and other forms of activity" (Creswell, 1994; Thomas, 1993). Creswell observes that "critical ethnographers attempt to aid emancipator goals, negate repressive influences, raise consciousness, and invoke a call to action that potentially will lead to social change (1994, p. 12)." This research was indeed local (secondary students in F \& CS classrooms in Erie, PA) and it expressed an agenda. That agenda was to identify and advance certain elements of student success not addressed by current educational policy (the standards movement).

For qualitative (ethnographies) and critical (critical ethnographies) research, the goal is to comprehend another person's subjective meaning, which is quite different from establishing the objective answers sought by normative science. Schutz held that the grasping of subjective meaning was the goal of social sciences and such data could only be garnered face-to-face (Polkinghorne, 1983, p. 209). However, some traditional researchers feel that such local and partial inquiries deny the possibility of knowledge detached from particular points of view. More moderate voices maintain that although one should be suspicious of such projects, their rejection leaves unanswered the question of how the human species will or can address the global problems that require informed action (Longino,1990, p. 213). The PRSM format that we used for analysis offers an opportunity to satisfy both moderate and hardline objectivists with further research. 
The solution lies in an iterative design process true to the feedback loop characteristic of systems practice. Phase 1 (student photoethnography), phase 2 (adult stakeholder criteria), and phase 3 (design charrette) should produce a design proposal suitable for implementation as a pilot public school F \& CS classroom. Additional qualitative research might result in a narrative describing use of the space by selected students over a limited time period. Quantitatively, schools could measure student performance over time (harmful behaviors, school success, etc.) before and after implementation to establish the impact of the design solution. Finally, both qualitative and quantitative results can provide data to be used in evidence-based design decisions, and approach used more frequently now in all areas of design.

Periodic Subjective Quantitative Measures. More broadly, the PRSM Matrix provides a method for ongoing collection and manipulation of rich and diverse data specific to our methodology across large populations. Non-specific "objective" measures for many of the 18 qualities of living have been readily available to statisticians in the form of banked survey and census data. These data have been used to "indicate" broader contributions to quality of life (infant mortality as an indicator of physical well-being, telephones per thousand as a cue to material satisfaction, etc.). However, there are issues with the validity of the indicators. Our preference would be for a subjective quantitative measure reporting experienced quality of living on an ongoing basis. There is ample precedent for subjective quantitative measures in our financial accounting system - balance sheets, income statements, Gross Domestic Product (GDP), etc.

If this F \& CS design prevailed, an annual quality-of-living measure using the PRSM matrix could be used to a) identify areas of maximum benefit for each year's mentoring focus and $b$ ) document student gains year to year. Reporting is simple. Within the matrix, each of the 18 cells operates as a flow model (Csikszentmihalyi, 1990). In the neutral state (0) skills and challenges are equal at a routine level. If skills are perceived to exceed challenges boredom ensues $(-1)$. Challenges exceeding available skills result in anxiety $\left(-1^{*}\right)$. The ideal state, flow, occurs when skills and challenges are matched at a level just beyond the routine. In the emotional-material realm cited as needing improvement by our respondents, the measure would be emotional well-being (skills) matched against challenges in the material dimension. In their newer minimalist classroom with gray walls, gray carpet and limited views, there was simply no stimulation. Our middle-class students were bored by their environment $(-1)$. The 1 's and 0 's logged in each report might be summed to measure individual development over time and/or class, school, state, region or national status and progress.

\section{Discussion: Suggestions for Future Research}

The study described in this article is a starting point for determining student needs in a classroom within a specific context. Future research is necessary to move the design of the $21^{\text {st }}$ century F \& CS classroom forward. Suggestions for future research in the context of the F \& CS classroom and other settings are listed below:

1. Additional studies collecting data from middle and high school students from different geographic and socio-economic levels are needed to broaden the vision of the classroom modifications discussed.

2. Similar studies may be conducted on classrooms with a different purpose than the $F$ \& CS classroom to determine how the specific use affects the needs of the students. 
3. Research focused on the pedagogy and classroom design comparing student needs using the PRSM model and matrix would help determine how the classroom design can more fully support a specific pedagogical approach.

4. A longitudinal study of student needs across their academic careers using the PRSM format would provide data on changes in quality of life needs as they age.

5. An annual survey tracking individuals' quality of living needs within different populations outside of the academic setting using the PRSM format would help to determine needs of a more diverse population.

\section{Conclusion}

While much of the information provided by the students within this study was not surprising, the seriousness with which they approached the project, and their complexity and depth of thought was impressive. The issue of supportive classroom design seemed important to them personally. The data from this study clearly indicate that students consistently identify similar issues that must be addressed in the redesign of their "student-centered" classroom spaces. Although mental requirements were largely fulfilled in this exemplary school system, the material environment was deemed insufficient to meet their emotional and physical needs, as was the social environment.

As interesting as these findings were, the real benefit of this research is in the methodology and analysis tool. Photoethnography offers a way to gather rich and complex data from untrained participants in a way that is fun for the participant. Individual interview follow-ups to the photographic sessions are important to allow researchers to understand the meaning behind the photos, and to let the students' voices be heard within the research results. The PRSM model and matrix offer a powerful tool for analysis of subjective and objective, qualitative and quantitative data. Together these methods and tools provide a coherent and sophisticated format for valuable and effective classroom research.

\section{References}

American Home Economics Association (AHEA). (1993). The Scottsdale Meeting: Position the profession for the 21st Century. Alexandria, VA: Author.

Berliner. (August, 2005). Our impoverished view of educational reform in Teachers College Record. Retrieved August 24, 2005 from http://www.tcrecord.org. ID Number: 12106.

Brazelton, T.B., \& Greenspan, S.I. (2000). The irreducible needs of children: What every child must have to grow and flourish. Cambridge, MA: Perseus Publishing.

Clark-Ibanez, M. (2004). Framing the social world with photo-elicitation interviews. American Behavioral Scientist, 47(12), $1507-1527$.

Colbert, J. (1997). Classroom design and how it influences behavior. Early Childhood News, 9 (3), $22-29$.

Creswell, J.W. (1994). Research Design: Qualitative and quantitative approaches. Thousand Oaks: Sage Publications. 
Csikszentmihalyi, M. (1990). Flow: The psychology of optimal experience. New York: Harper.

Dodd, A.W. (1997). Creating a climate for learning: Making the classroom more like an ideal home. NASSP Bulletin, 81(589), $10-16$.

Drucker, P.F. (1999). Management challenges for the 21st century. New York: HarperBusiness.

Fredericks, J.A., Blumenfeld, P.C., \& Paris, A.H. (2004). School engagement: Potential of the concept, state of the evidence. Review of Educational Research, 74(1), 59-109.

Garbarino, J. (1999). Lost boys: Why our sons turn violent and how we can save them. New York: Anchor Books.

Gonzales, P., Williams, T., Jocelyn, L., Roey, S., Kastberg, D., \& Brenwald, S. (2008). Highlights from TIMSS 2007: Mathematics and Science achievement of U.S. fourth- and eight-grade students in an international context (NCES 2009-001). National Center for Education Statistics, Institute of Education Services, U.S. Department of Education. Washington, DC., pp. 25 and 50.

The High School Survey of Student Engagement (HSSSE): What we can learn from high school Students. (2005). Bloomington, IN, Indiana: Indiana University, HSSE

Jenks, C.L. (2001). Missing links in the public school curriculum: Four dimensions for change. Novato, California: Buck Institute for Education.

Longino, H. (1990). Science as social knowledge: Values and objectivity in scientific inquiry. Princeton: Princeton University Press.

Martin, J.R. (1992). The schoolhome: Rethinking schools for changing families. Need publisher.

McFall, B. \& Mitstifer, D.I. (2005, November). A Century of Change: Repositioning FCS as a Foundation for Lifelong Learning. For the Journal of Family and Consumer Sciences.

McFall, B.S. (1998). Personal Resource Systems Management (PRSM): A proposal for interactive practice. Unpublished master's thesis. Virginia Polytechnic Institute and State College, Blacksburg, VA.

McFall, B.S. (2002). Future Promise: Designing Personal Resource Systems Management as a platform for quality of living and learning. Ann Arbor, MI: UMI Dissertation Services.

National Research Council. (2004). Engaging schools: Fostering high school students' motivation to learn. Washington, DC: The National Academics Press.

Norris, C., Pignal, J., \& Lipps, G. (2003). Measuring school engagement. Education Quarterly Review, $9(2), 25-34$.

Peters, T. (1994). The pursuit of WOW! Every person's guide to topsy-turvy times. New York: Vantage Books.

Polkinghorne, D. (1983). Methodology for the Human Sciences: Systems of inquiry. Albany: Stat University of New York Press. 
Rose, L.C., \& Gallup, A.M. (2000). The 32nd annual Phi Delta Kappa/Gallup poll of the public's attitudes toward the public schools. Retrieved August 23, 2005 from http://www.pdkintl.org/kappan/kpol0009.htm

Rose, L.C., \& Gallup, A.M. (2005). The 36th annual Phi Delta Kappa/Gallup poll of the public's attitudes toward the public schools. Retrieved August 23, 2005 from http://www.pdkintl.org/kappan/k0409pol.htm

Search Institute. (1997a). The asset approach: Giving kids what they need to succeed [Pamphlet]. Minneapolis, MN: Author.

Search Institute. (1997b). The power of developmental assets. In Healthy communities, healthy youth: A national initiative of the Search Institute to unite communities for children and adolescents [Brochure]. Minneapolis, MN: Author. Web site: http://www.search-institute.org

Search Institute. (2005). Updated profiles of student life: Attitudes and behaviors data set. Retrieved June 15, 2005 from http://www.search-institute.org

Sergiovanni, T.J. (1992). Building community in schools. San Francisco: Josey-Bass.

Taylor, A. (2001). Programming and design of schools within the context of community. Retrieved August 12, 2004 from http://www.designshare.com/Research/Taylor/Taylor Programming 5.htm

Thomas, J. (1993). Doing critical ethnography. Newberry Park, CA: Sage.

Turkheimer, E., Haley, A., Waldron, M., D’Onofrio, B. \& Gottesman, I. (2003). Socioeconomic status modifies hereditability of IQ in young children. Psychological Science, 14(6), 623-628.

U. S. Department of Health and Human Services, Center for Disease Control and Prevention, National Center for Health Statistics. (July 24, 2000). Deaths and death rates for the 10 leading causes of death in specified age groups by race and sex: United States 1996present. In National Vital Statistics Reports, 48(11). Washington, DC: Author. Retrieved May 7, 2001 from http://www.cdc.gov/nchs/fastats/suicide.htm

Wallen, N.E. \& Fraenkel, J.R. (1991). Educational Research: A guide to the process. New York: McGraw-Hill.

(C) Copyright of Journal of Youth Development $\sim$ Bridging Research and Practice. Content may not be copied or emailed to multiple sites or posted to a listserv without copyright holder's express written permission. However, users may print, download or email articles for individual use. 